\title{
Article \\ Categorization of Marketed Artificial Tear Formulations Based on Their Ingredients: A Rational Approach for Their Use
}

\author{
Avani Kathuria ${ }^{1}$, Kiumars Shamloo ${ }^{1}$, Vishal Jhanji ${ }^{2}$ and Ajay Sharma ${ }^{1, *}$ D \\ 1 Chapman University School of Pharmacy, Chapman University, Irvine, CA 92618, USA; \\ kathu101@mail.chapman.edu (A.K.); shaml103@mail.chapman.edu (K.S.) \\ 2 Department of Ophthalmology, School of Medicine, University of Pittsburgh School of Medicine, \\ Pittsburgh, PA 15213, USA; jhanjiv@upmc.edu \\ * Correspondence: sharma@chapman.edu; Tel.: +1-714-516-5498
}

check for updates

Citation: Kathuria, A.; Shamloo, K.; Jhanji, V.; Sharma, A. Categorization of Marketed Artificial Tear Formulations Based on Their Ingredients: A Rational Approach for Their Use. J. Clin. Med. 2021, 10, 1289 https://doi.org/10.3390/jcm10061289

Academic Editor: Piera Versura

Received: 5 March 2021

Accepted: 18 March 2021

Published: 21 March 2021

Publisher's Note: MDPI stays neutral with regard to jurisdictional claims in published maps and institutional affiliations.

Copyright: (c) 2021 by the authors. Licensee MDPI, Basel, Switzerland. This article is an open access article distributed under the terms and conditions of the Creative Commons Attribution (CC BY) license (https:// creativecommons.org/licenses/by/ $4.0 /)$.

\begin{abstract}
Dry eye disease is a common ocular condition affecting millions of people worldwide. Artificial tears are the first line therapy for the management of dry eye disease. Artificial tear formulations contain a variety of active ingredients, biologically active excipients, and preservatives. Many of these formulations are also available as preservative-free. This study was conducted to inspect artificial tear formulations currently marketed in the United States for their active ingredients, biologically relevant excipients, and preservatives. The marketed artificial tears were examined at various US retail pharmacy chains and using the manufacturers' website to compile information about active ingredients, inactive ingredients, and preservatives. The currently marketed artificial tears can be grouped into four categories based on their active ingredients. The artificial tears also contain biologically active chemicals listed as inactive ingredients, which have osmoprotectant, humectant, and tear film lipid layer or mucous layer mimicking properties. Most artificial tears contain vanishing type preservatives such as purite or sodium perborate and safer quaternary compound polyquaternium-1. The majority of these artificial tear formulations are also available as preservative-free single dose unit. The study provides a formulary of artificial tears based on active ingredients, biologically active excipients, and the preservative-free option. The formulary should assist healthcare providers in making a stepwise and rational selection of appropriate artificial tears for patients suffering from dry eye disease.
\end{abstract}

Keywords: artificial tears; dry eye; demulcents; ophthalmic preservatives; osmoprotectants; humectants

\section{Introduction}

Dry eye disease is a common ocular condition affecting millions of people all over the world. According to National Health and Wellness Survey, an estimated 16.4 million people in the United States suffer from dry eye disease [1]. As per the current Tear Film \& Ocular Surface Society (TFOS) definition, dry eye is a multifactorial disease characterized by loss of tear film homeostasis, tear hyperosmolarity, ocular surface inflammation, and neurosensory abnormalities [2]. The condition can cause a wide array of symptoms such as redness, stringy mucous, burning, and itchy sensation. Left untreated, the disease can result in visual disturbance and tear film instability with potential damage to the ocular surface [3]. Since the disease can significantly impact professional, social, and leisure activities, it leads the patient either to self-medicate with over-the-counter products or to seek medical help. Although the symptoms may improve or worsen over the natural course of the disease, dry eye disease is considered a lifelong condition [4]. Pharmacological and nonpharmacological interventions significantly improve the symptoms, however long-term adherence to these approaches is necessary for the effective management of dry eye disease. Detailed patient history, clinical examination, and diagnostic tests can play a very important role in effective management of this multifactorial disease [4]. A thorough clinical workup can also identify any underlying conditions or systemic diseases contributing to dry eye, 
since treating these underlying conditions is imperative for the effective management of dry eye disease [4].

Tear film is composed of a muco-aqueous layer underlying a lipid layer. It contains oxygen, metabolites, antimicrobials, and proteins [5]. The importance of tear film in keeping the ocular surface healthy has long been recognized, since it serves to provide nutrients, moisture, smooth the optical surface as well as helps to remove microbes. Tear replacement remains one of the mainstay approaches for the treatment of dry eye $[4,6]$. Although artificial tears are not meant to recapitulate the functions of natural tears, they do provide remarkable symptomatic and palliative relief in dry eye [4,6]. In 2018, artificial tears accounted for $\$ 2.2$ billion in global sales, and their market continues to grow [7]. Healthcare providers play a critical role in guiding patients to choose the most appropriate artificial tear product. However, recommending the right artificial tear product can be difficult for many reasons. A vast number of artificial tear products are currently available in the United States. These artificial tears contain a wide variety of active ingredients and come in multidose vials with preservative or as preservative-free single dose units. Many of these artificial tears also contain excipients that are listed under inactive ingredients, but these excipients are known to contribute to their therapeutic benefits. Despite such a large variety of artificial tears, there is a paucity of information with up-to-date classification of marketed artificial tears based on their active and pharmacological relevant inactive ingredients, as well as their availability with or without preservatives. The aim of this study was to screen and categorize marketed artificial tear formulations based on their active ingredients, biologically relevant excipients, and preservatives. The information should help healthcare providers with the knowledge about which artificial tears they can initially choose and then switch to the ones with additional biologically active ingredients or another class with a different active ingredient.

\section{Materials and Methods}

The marketed artificial tears were surveyed at various US retail pharmacy chains and using the manufacturers' website to compile the information about active ingredients, inactive ingredients, and preservatives. The artificial tear preparations were then tabulated based on the major active ingredient and the biologically active excipients listed under inactive ingredients. The type of preservative present in the formulations was noted, and it was also determined if these formulations were available as preservative-free single dose application units.

\section{Results}

\subsection{Active Ingredients in Artificial Tears}

Artificial tears contain one or more FDA-approved demulcents as active ingredient [8]. FDA defines demulcent as a primarily water-soluble polymer, which is applied topically to the eye to protect and lubricate mucous membrane surfaces and relieve dryness and irritation. The list of these demulcents and their concentration range was provided by the FDA in a 1988 monograph to help reduce the costs and expedite approval of artificial tears [8]. The FDA approved demulcents include (a) Cellulose derivatives: Carboxymethylcellulose (CMC), Hydroxypropyl methylcellulose (hypromellose), Hydroxyethylcellulose, Methylcellulose, (b) Dextran 70, (c) Gelatin, (d) Polyols: Glycerin, Polyethylene glycol (300, 400), Polysorbate 80, (e) polymers: Polyvinyl alcohol, Polyvinyl pyrrolidone (povidone).

Our screening data demonstrates that the currently marketed tears contain CMC, hypromellose, dextran, glycerin, polyethylene glycol 400 , polysorbate 80 , polyvinyl alcohol, and povidone as active ingredients (Tables $1-4$ ). However, there are no currently marketed artificial tears that contain hydroxyethyl cellulose, methylcellulose, gelatin, or polyethylene glycol 300. CMC is a polysaccharide with mucoadhesive properties and has been shown to bind to corneal epithelial cells. It enhances tear viscosity and increases the precorneal residence time of artificial tears at $1 \%$ concentration [9]. CMC is the primary active ingredient in Thera tears ${ }^{\circledR}$ (Akorn Consumer Health, Ann Arbor, MI, USA) and Refresh ${ }^{\circledR}$ brand 
(Allergan, Irvine, CA, USA) of artificial tears, with some formulations of the latter brand also containing glycerin and polysorbate 80 (Table 1). HPMC, better known as hypromellose, is also a polysaccharide polymer produced from cellulose. Hypromellose helps to moisten and lubricate the eye surface. Hypromellose along with dextran and glycerin are the demulcent and humectants in the GenTeal ${ }^{\circledR}$ brand (Alcon, Fort Worth, TX, USA) of tears (Table 2). Further, our data analysis shows that propylene glycol, polyethylene glycol 400 , and glycerin are three main polyol demulcents in currently marketed artificial tears (Table 3). Propylene glycol and glycerin also act as humectants to retain moisture at the ocular surface. The Systane ${ }^{\circledR}$ brand (Alcon, Fort Worth, TX, USA) has two formulations: Systane Balance ${ }^{\circledR}$ and Systane Complete ${ }^{\circledR}$, with exact identical composition having propylene glycol as the active ingredient. However, these two formulations have significantly different physicochemical characteristics, with Systane Balance ${ }^{\circledR}$ as microemulsion and Systane Complete ${ }^{\circledR}$ as a nanodrop formulation [10]. Three other formulations from Systane ${ }^{\circledR}$ are Original ${ }^{\circledR}, \mathrm{Ultra}^{\circledR}$, and Gel ${ }^{\circledR}$, which contain propylene glycol plus polyethylene glycol as active ingredients but differ in their physicochemical properties- especially viscosity and biological properties-as well despite having a similar composition [10]. Soothe ${ }^{\circledR}$ drops (Bausch + Lomb, Bridgewater, NJ, USA) also contain both glycerin and propylene glycol as its active ingredients (Table 3). Oasis ${ }^{\circledR}$ brand drops (Oasis Medical, Inc., Glendora, CA, USA) and Blink ${ }^{\circledR}$ tears (Johnson \& Johnson Vision, Jacksonville, FL, USA) contain glycerin and polyethylene glycol alone, respectively as demulcent (Table 3).

Table 1. Artificial tears containing Carboxymethylcellulose (CMC) as a demulcent.

\begin{tabular}{|c|c|c|c|}
\hline \multirow{2}{*}{ Active Ingredient(s) } & \multirow{2}{*}{$\begin{array}{l}\text { Inactive Ingredients with } \\
\text { Biological Activity }\end{array}$} & \multicolumn{2}{|c|}{ Brand } \\
\hline & & With Preservative & Preservative Free \\
\hline CMC $0.25 \%$ & & Thera Tears ${ }^{\circledR}$ (Dequest) & Thera Tears ${ }^{\circledR}$ \\
\hline CMC $0.25 \%$ & Trehalose & Thera Tears Extra ${ }^{\circledR}$ (Dequest) & \\
\hline CMC $0.5 \%$ & & Refresh Tears ${ }^{\circledR}$ (Purite) & Refresh Plus ${ }^{\circledR}$ \\
\hline CMC $0.5 \%$ Glycerin $0.9 \%$ & Erythritol L-Carnitine & Refresh Optive $^{\circledR}$ (Purite) & Refresh Optive $^{\circledR}$ \\
\hline CMC $0.5 \%$ Glycerin $0.9 \%$ & Erythritol Sodium hyaluronate & Refresh Repair $^{\circledR}$ (Purite) & \\
\hline $\begin{array}{l}\text { CMC 0.5\% Glycerin } 1 \% \\
\text { Polysorbate80 0.5\% }\end{array}$ & Erythritol L-Carnitine Castor oil & Refresh Optive advanced $^{\circledR}$ (Purite) & Refresh Optive advanced ${ }^{\circledR}$ \\
\hline $\begin{array}{l}\text { CMC } 0.5 \% \text { Glycerin } 1 \% \\
\text { Polysorbate } 800.5 \%\end{array}$ & $\begin{array}{l}\text { Erythritol L-Carnitine Trehalose } \\
\text { Castor oil Flaxseed oil }\end{array}$ & & Refresh Optive Mega- $3^{\circledR}$ \\
\hline CMC $1 \%$ & & Refresh Liquigel $^{\circledR}$ (Purite), & $\begin{array}{l}\text { Refresh Celluvisc }^{\circledR} \\
\text { Thera tears Liquigel }^{\circledR}\end{array}$ \\
\hline CMC $1 \%$ Glycerin $0.9 \%$ & Erythritol L-Carnitine & Refresh Optive Gel ${ }^{\circledR}$ (Purite) & \\
\hline
\end{tabular}

Table 2. Artificial tears containing hypromellose and dextran as demulcents.

\begin{tabular}{|c|c|}
\hline Active Ingredient(s) & Brand \\
\hline Hypromellose $0.3 \%$ Dextran $0.1 \%$ & GenTeal Mild $^{\circledR}$ (Polyquaternium-1) \\
\hline Hypromellose $0.3 \%$ Dextran $0.1 \%$ Glycerin $0.2 \%$ & $\begin{array}{c}\text { GenTeal Moderate }^{\circledR} \text { (Polyquaternium-1) Also available as } \\
\text { preservative free }\end{array}$ \\
\hline $\begin{array}{c}\text { Hypromellose } 0.3 \%+\text { Carbopol } 980 \\
\text { Hypromellose } 0.3 \%\end{array}$ & $\begin{array}{c}\text { GenTeal Severe }^{\circledR} \\
\text { Systane lubricant eye gel }{ }^{\circledR} \text { (Sodium perborate) }\end{array}$ \\
\hline
\end{tabular}


Table 3. Artificial tears containing propylene glycol, polyethylene glycol, and glycerin as demulcents.

\begin{tabular}{|c|c|c|c|}
\hline \multirow{2}{*}{ Active Ingredient(s) } & \multirow{2}{*}{$\begin{array}{l}\text { Inactive Ingredients with } \\
\text { Biological Activity }\end{array}$} & \multicolumn{2}{|c|}{ Brand } \\
\hline & & With Preservative & Preservative Free \\
\hline Propylene Glycol 0.6\% & $\begin{array}{c}\text { Dimyristoyl phosphatidyl } \\
\text { glycerol Hydroxypropyl guar } \\
\text { Mineral oil }\end{array}$ & $\begin{array}{l}\text { Systane Balance }^{\circledR} \\
\text { Systane Complete }^{\circledR} \\
\text { (nanodrops) } \\
\text { (Polyquaternium-1) }\end{array}$ & \\
\hline $\begin{array}{l}\text { Propylene Glycol 0.3\% } \\
\text { Polyethylene Glycol 0.4\% }\end{array}$ & $\begin{array}{c}\text { Hydroxypropyl guar } \\
\text { Sodium hyaluronate (only in } \\
\text { Hydration }^{\circledR)}\end{array}$ & $\begin{array}{l}\text { Systane Original }{ }^{\circledR} \\
\text { Systane Ultra }{ }^{\circledR} \\
\text { Systane Gel Drops }{ }^{\circledR} \\
\text { (Polyquaternium-1) }\end{array}$ & $\begin{array}{c}\text { Systane Original }^{\circledR} \\
\text { Systane Ultra }^{\circledR} \\
\text { Systane Hydration }^{\circledR}\end{array}$ \\
\hline Glycerin $0.22-0.25 \%$ & Sodium hyaluronate & & $\begin{array}{c}\text { Oasis tears }^{\circledR} \\
\text { Oasis tears plus }^{\circledR}\end{array}$ \\
\hline Polyethylene Glycol $0.25 \%$ & Sodium hyaluronate & $\begin{array}{l}\text { Blink Tears Blink Gel Tears }{ }^{\circledR} \\
\text { (Sodium Chlorite) }\end{array}$ & Blink Tears ${ }^{\circledR}$ \\
\hline $\begin{array}{c}\text { Glycerin } 0.6 \% \\
\text { Propylene Glycol } 0.6 \%\end{array}$ & & & Soothe ${ }^{\circledR}$ \\
\hline
\end{tabular}

Table 4. Artificial tears containing povidone and polyvinyl alcohol as demulcents.

\begin{tabular}{|c|c|c|}
\hline \multirow{2}{*}{ Active Ingredient(s) } & \multicolumn{2}{|l|}{ Brand } \\
\hline & With Preservative & Preservative Free \\
\hline Povidone $1.25 \%$ & Soothe Hydration ${ }^{\circledR}$ (EDTA) & \\
\hline Povidone $2 \%$ & Soothe maximum hydration ${ }^{\circledR}$ (Benzalkonium Chloride) & \\
\hline Polyvinyl alcohol 1.4\% & Akorn ${ }^{\circledR}$ artificial tears (Benzalkonium Chloride) & \\
\hline $\begin{array}{c}\text { Povidone } 0.6 \% \\
\text { Polyvinyl alcohol } 0.5 \%\end{array}$ & Murine $^{\circledR}$ tears (Benzalkonium Chloride) & \\
\hline $\begin{array}{c}\text { Povidone } 2 \% \\
\text { Polyvinyl alcohol } 2.7 \%\end{array}$ & & FreshKote $^{\circledR}$ \\
\hline
\end{tabular}

Our screening shows that povidone is the primary demulcent in Soothe hydration ${ }^{\circledR}$ and maximum hydration brand eye drops, while polyvinyl alcohol is the demulcent in Akorn ${ }^{\circledR}$ artificial tears (Akorn, Lake Forest, IL, USA). Murine ${ }^{\circledR}$ tears and FreshKote ${ }^{\circledR}$ (Eyevance Pharmaceuticals, Fort Worth, TX, USA) use a combination of povidone and polyvinyl alcohol (Table 4).

\subsection{Biologically Active Excipients in Artificial Tears}

One downside of the FDA's pre-approved monograph is that if a developer lists an active ingredient that is not on the FDA monograph, they need to provide clinical data proving the safety of its ophthalmic use in humans. Many pharmaceutical excipients and food additives have been shown to provide therapeutic relief in dry eye disease. Although these excipients and additives have ophthalmic therapeutic potential, the manufacturers list them under inactive ingredients in artificial tears to avoid trials. Because of their notable biological activity, health care providers need to be aware of these excipients and additives. Therefore, we carefully reviewed the biologically active pharmaceutical excipients and food additives present in these drops.

Our survey data shows that the currently marketed artificial tears use the following biologically active pharmaceutical excipients and food additives: (a) Osmoprotectants: trehalose, erythritol, levocarnitine, (b) Humectants: sodium hyaluronate, (c) Hydroxypropyl Guar gum, (d) Oils: flaxseed oil, castor oil, mineral oil. 
Osmoprotectants are agents that protect cells against hyperosmolar stress-mediated injury. Since hyperosmolarity is one the characteristics of dry eye, osmoprotectants are emerging ingredients of artificial tears. Levocarnitine (L-carnitine) is present in prokaryotic and eukaryotic cells, including human corneal and conjunctival epithelia [11,12]. Erythritol is polyol used as a low-calorie sweetener. In vitro studies using cultured human corneal epithelial cells demonstrate that osmoprotectants are taken up by the dehydrated cells, then restore volume and prevent protein denaturation $[13,14]$. Trehalose is a naturally occurring disaccharide consisting of two alpha-glucose units joined by glucoside bond. Trehalose has also been shown to protect corneal epithelial cells from desiccation and high osmolarity [15-17]. Our data analysis demonstrated that erythritol, L-carnitine, and trehalose are present in some Refresh ${ }^{\circledR}$ brand artificial tears, which contain CMC as the main demulcent (Table 1).

Humectants are hygroscopic agents that facilitate the retention of water. Hyaluronic acid is a high molecular weight naturally occurring glycosaminoglycan polysaccharide $[18,19]$. It is present in connective tissue, synovial fluid, and in the aqueous humor, and is vitreous $[18,19]$. Hyaluronic acid acts as a humectant and can bind water multiple times the amount of its weight. Sodium hyaluronate is a semisynthetic smaller molecular weight sodium salt derivative of hyaluronic acid. Like hyaluronic acid, sodium hyaluronate also acts as a humectant to provide additional hydration. Its mucoadhesive properties are proposed to increase the corneal residence time. Our data demonstrates that sodium hyaluronate is present in three artificial tear formulations with CMC, glycerin, and polyethylene glycol as demulcents (Tables 1 and 3). It is worthwhile to note that in many artificial tears marketed in Europe and Asia (e.g., Hylo brand tears ${ }^{\circledR}$, Vismed Multi ${ }^{\circledR}$, Xailin $\mathrm{HA}^{\circledR}$, Thealoz Duo ${ }^{\circledR}$, BLUyal OSD $^{\circledR}$, Hyalistil Bio $^{\circledR}$, Artelac ${ }^{\circledR}$ Splash $^{\mathrm{TM}}$, Zolag $^{\circledR}$ ), sodium hyaluronate is listed as an active ingredient, because unlike the FDA, agencies in these countries do not have a list of demulcents for expediated approval.

Hydroxypropyl guar is a viscous protein polymer derived from beans. Upon instillation, hydroxypropyl guar forms a soft gel with increased viscosity at the tear $\mathrm{pH}$. It mimics the properties of mucin layer by strengthening the attachment of the aqueous layer to the mucins and promotes the retention of other demulcents [20,21]. It has also been shown to stabilize the tear film. Hydroxypropyl guar is present in all Systane ${ }^{\circledR}$ brand artificial tears (Table 3).

Flaxseed oil, castor oil, and mineral oil mimic the lipid layer of tear film, stabilize tear film, increase lipid layer thickness, and prevent evaporation [22-24]. Our survey demonstrates that among the currently marketed artificial tears, two Refresh brand formulations contain castor oil, flaxseed oil, and polysorbate 80 with CMC as a demulcent (Table 1). Two Systane ${ }^{\circledR}$ brand formulations contain mineral oil and phospholipid dimyristoyl phosphatidylglycerol with propylene glycol as demulcent (Table 3). Polysorbate 80 and dimyristoyl phosphatidylglycerol in these formulations act as emulsifiers in these formulations, but also have additional biological advantage to help spread and stabilize the lipid layer upon instillation [10]. All these oils containing artificial tear formulations are emulsions.

\subsection{Preservatives in Artificial Tears}

Ophthalmic formulations are required to be sterile for the obvious reason of protecting the eye from infections. To maintain the sterility, artificial tears as a multidose ophthalmic formulation need to contain preservatives or alternatively need to be packaged as preservative-free single dose units. Based on our survey, the currently marketed artificial tears use purite, polyquaternium-1, sodium perborate, and benzalkonium chloride as preservatives with only one brand Blink ${ }^{\circledR}$ Tears using sodium chlorite (Tables 1-4). Many of these drops are also available in preservative-free single dose units. Refresh ${ }^{\circledR}$ brand of tears contains purite as a preservative in their formulation but also offer most of their tears in a preservative-free form (Table 1). Sodium perborate is the preservative in Thera Tears ${ }^{\circledR}$ and GenTeal ${ }^{\circledR}$ brand tears (Tables 1 and 2). Polyquaternium (Polyquad) 
is the preservative present in GenTeal ${ }^{\circledR}$ and Systane ${ }^{\circledR}$ brand tears. All the artificial tears with povidone and polyvinyl alcohol use benzalkonium chloride as a preservative except FreshKote ${ }^{\circledR}$ which is available preservative-free (Table 4). Interestingly, Europe has many artificial tears available in multidose special ophthalmic dispensers. These multidose artificial tears are preservative-free, since the special dispensers are designed to prevent microbial contamination.

\section{Discussion}

Demulcents are the primary active ingredient for artificial tears. Our data analysis shows that there are primarily four categories of artificial tears to select from based on the demulcent present in them. Two brands contain CMC as demulcents, with Thera Tears ${ }^{\circledR}$ containing the lowest concentration of $\mathrm{CMC}$ at $0.25 \%$. These drops are a great option for patients with milder symptoms of dry eye who better tolerate lower concentrations of CMC. Thera Tears ${ }^{\circledR}$ are available in multidose vial containing the vanishing preservative sodium perborate or as preservative-free single application. Thera Tears extra ${ }^{\circledR}$ with $0.25 \%$ CMC plus trehalose as an additional ingredient are available only as sodium perborate preservative containing multidose vial. Sodium perborate, also known as Dequest, is a vanishing type of preservative. In solution, it is converted to hydrogen peroxide and causes the bactericidal effect by oxidative stress-mediated denaturation of bacterial proteins. Upon instillation into an eye, it is converted to oxygen and water by the enzyme catalase. Sodium perborate is less toxic than benzalkonium chloride but not completely innocuous $[25,26]$. Therefore, preservative-free Thera Tears ${ }^{\circledR}$ should be preferred if a patient needs more than four applications per day.

Refresh ${ }^{\circledR}$ brand of artificial tears have several formulations containing 0.5\% CMC alone, with additional demulcents and biologically active excipients like osmoprotectants erythritol, l-carnitine, and trehalose. L-carnitine and erythritol have been shown to attenuate hyperosmolar stress-mediated increase in MAP kinases, pro-inflammatory cytokines, and matrix metalloproteases in corneal epithelial cells [27-30]. Clinical studies demonstrate that artificial tears containing L-carnitine and erythritol reduce tear osmolarity and provide symptomatic relief [31-33]. Studies in animal models of dry eye and clinical studies with trehalose containing eye drops demonstrate many beneficial effects, including increased tear production, tear stabilization, reduced corneal staining, and a decrease in corneal epithelial cell apoptosis [34-37]. Humectant sodium hyaluronate in Refresh ${ }^{\circledR}, \mathrm{Oasis}^{\circledR}$ and Blink $^{\circledR}$ tears can offer significant additional relief in dry eye in preventing or treating corneal epithelial damage since in vitro studies demonstrate that sodium hyaluronate promotes corneal epithelial cell migration and proliferation, thus facilitating healing [38-40]. Topical application of sodium hyaluronate in rabbits and mice has been shown to promote wound healing and relieve dry eye symptoms [41,42]. Castor oils and flaxseed oil in some Refresh ${ }^{\circledR}$ Brand tears will offer the additional benefit of reduced tear evaporation in patients with evaporative dry eye. Purite, the preservative present in Refresh ${ }^{\circledR}$ brand artificial tears, is stabilized oxychloro complex (SOC) containing $99.5 \%$ chlorite, $0.5 \%$ chlorate. In solution, its bactericidal action is mediated by the oxidizing action of chlorine dioxide free radical. It belongs to the vanishing class of artificial tears since upon instillation, it is converted to sodium chloride, oxygen, and water $[43,44]$. Animal studies demonstrate that purite is significantly less toxic to corneal epithelium compared to benzalkonium chloride but has some degree of detrimental effect compared to preservative-free artificial tears [43-47]. Given the wide variety of options, a patient can be started on Refresh ${ }^{\circledR}$ tears with CMC alone either with or without preservatives depending upon the frequency of instillation required and if the dry eye relief is inadequate, Refresh ${ }^{\circledR}$ tears with additional biologically active excipients can be tried.

The Systane ${ }^{\circledR}$ brand of tears use propylene glycol and glycerin as demulcent and humectants to retain moisture at ocular surfaces along with dimyristol phosphatidyl glycerol, hydroxy propyl guar, and mineral oil listed under inactive ingredients purportedly mimicking the mucin and the lipid component of tear film and polyquaternium- 1 as a 
preservative. In an in vitro model of 3D corneal epithelium, the dual polymer formulation of hydroxypropyl guar/sodium hyaluronate demonstrated enhanced the ocular surface hydration, surface retention, cell barrier function, and lubricity compared to single-polymer formulations $[19,20]$. Polyquaternium (Polyquad) is a commonly used preservative in Systane ${ }^{\circledR}$ ophthalmic drops. This compound is a quaternary ammonium compound and has bactericidal activity due to the surfactant action just like benzalkonium chloride. However, this compound is a large size polymer and is safe for mammalian cells, apparently due to its reduced penetration owing to its larger size $[43,48]$. Several in vitro and animal studies have compared the ocular surface toxicity of polyquaternium and benzalkonium chloride. In vitro studies demonstrate that polyquaternium has low cytotoxicity and it is remarkably safer than benzalkonium chloride [49-52]. Further, it seems to be well tolerated upon topical instillation in animal studies and in patients taking polyquaternium preserved glaucoma drops [53-56].

Benzalkonium chloride is another common preservative used in ophthalmic drops. However, our data reveals that among the current brand name artificial tears, only Soothe ${ }^{\circledR}$, Akron $^{\circledR}$, and Murine ${ }^{\circledR}$ brand tears use benzalkonium chloride as a preservative. Benzalkonium chloride is an amphiphilic quaternary ammonium compound that kills bacteria by surfactant action on their plasma membrane. However, mammalian cells, including the corneal and conjunctival epithelial cells can also be impacted by the surfactant action of benzalkonium chloride. In vitro studies using corneal and conjunctival epithelial cells demonstrate that benzalkonium chloride decreases ocular surface epithelial cell viability and increases the release of pro-inflammatory mediators [57-61]. Topical application of benzalkonium chloride in rabbits and rodents has been demonstrated to cause tear film abnormalities, reduction in mucins and goblet cell density, corneal epithelial desquamation, and an influx of inflammatory cells [62-66]. Further studies in rodents revealed detrimental changes in corneal innervation after topical application of benzalkonium chloride $[67,68]$. Glaucoma patients using benzalkonium chloride-containing eye drops have been reported to suffer from reduced tear film and tear breakup time, as well as increased tear osmolarity $[43,69]$. As observed in the animal studies, prolonged use of benzalkonium chloride containing eye drops in glaucoma patients has also been shown to cause damage to the ocular surface epithelial cells and corneal nerves [43]. Since many of the observed toxic effects of benzalkonium chloride can exacerbate ocular surface damage and further worsen the inflammatory response, the current consensus is to avoid the use of benzalkonium chloride containing artificial tears in dry eye patients.

\section{Conclusions}

The goal of screening the marketed artificial tear formulations was to give health care providers a formulary of artificial tears classified based on their active ingredients and biologically active excipients. The options of preservative-free single dose units, if available, has also been included in our data tables. The compiled information should assist the healthcare providers to make a stepwise and rational selection of appropriate artificial tears for the patients based on the active ingredients and biologically active excipients.

Due to the multifactorial etiology of dry eye, it is challenging to make generalized recommendations about selecting appropriate artificial tears. However, based on recent studies and clinical experience, some broad suggestions are available to make a judicious selection $[37,70-75]$. Individualized artificial tear therapy needs to be based on patient's history, ocular examination, and clinical testing. Patients having mild increase in tear osmolarity and normal tear break up time (TBUT) can be managed with artificial tears containing one or two demulcents such as CMC (Thera Tears ${ }^{\circledR}$; Refresh Tears ${ }^{\circledR}$ ), hypromellose plus dextran $\left(\right.$ GenTeal Mild ${ }^{\circledR}$ ), or polyols (Soothe ${ }^{\circledR}$, Systane Original ${ }^{\circledR}$, Systane Ultra ${ }^{\circledR}$ ). Thera tears are hypo-osmolar and have a slightly alkaline $\mathrm{pH}$ that may offer a more soothing effect for some patients. If monitoring reveals inadequate response, formulation with added excipients such as osmoprotectants and sodium hyaluronate can be tried (Thera Tears Extra ${ }^{\circledR}$, Refresh Optive ${ }^{\circledR}$, Refresh Repair ${ }^{\circledR}$, Oasis $^{\circledR}$, Blink Tears ${ }^{\circledR}$ ). Awareness about 
artificial tears based on different demulcents as active ingredients can help one make a rational switch from one class of active ingredient to another class in the case of inadequate relief. Cases with a moderate increase in osmolarity and quick TBUT may denote significant evaporative dry eye. Dry eye due to meibomian gland dysfunction also has significant evaporative component due to deficiency in the lipid layer. In such cases, artificial tears that contain lipid components including castor oil (Refresh Optive Advance ${ }^{\circledR}$ ), flaxseed oil (Refresh Optive Omega $3^{\circledR}$ ), mineral oil, and dimyristoyl phosphatidyl glycerol (Systane Balance ${ }^{\circledR}$, Systane Complete ${ }^{\circledR}$ ) that either replenish or stabilize the lipid layer should be considered. Formulations with unique bioactive excipients, such as dimyristoyl phosphatidyl glycerol and hydroxypropyl guar, may work better for some patients (Systane Original ${ }^{\circledR}$, Systane Ultra ${ }^{\circledR}$, Systane Balance ${ }^{\circledR}$, Systane Complete ${ }^{\circledR}$ ). The awareness about the availability of preservative-free formulations in each category is also critical. The option should be discussed with the patient whether they can afford preservative-free artificial tears and are willing to try them. Preservative-free formulations are recommended for patients requiring more than four to six applications per day.

Cases with moderate to high increase in osmolarity and significant ocular surface staining invariably require prescription based anti-inflammatory drops. The importance of lifestyle and dietary modification should be emphasized during counseling and is helpful for all types of dry eye patients. Warm compresses and lid hygiene are also critical for meibomian gland dysfunction. Use of gels and nighttime ointments is also an option for moderate cases. Ointments are exclusively for nighttime use but some gel formulations (Refresh Liquigel ${ }^{\circledR}$, Refresh Celluvisc ${ }^{\circledR}$, Refresh Optive Gel ${ }^{\circledR}$, Systane Gel Drops ${ }^{\circledR}$, Blink Gel Tears ${ }^{\circledR}$ ) can be used during both the day and nighttime. Patients need to be counselled on transient blurring of vision with the daytime use of gels.

Several clinical studies have tested the efficacy of artificial tears in patients suffering from dry eye. These trials have been extensively reviewed [37,70-75]. Although no conclusive recommendations demonstrate the efficacy of one class of artificial tears is superior over another class due to variability in the study design, tested clinical end points, patients' heterogeneity, and sponsor bias [70,71], nonetheless, these trials consistently demonstrate that artificial tears show therapeutic benefits and are useful armaments in the management of dry eye.

Author Contributions: Data curation, A.K.; Formal analysis, A.K. and A.S.; Methodology, A.K. and K.S.; Project administration, A.S.; Resources, A.S.; Writing-original draft, A.S.; Writing-review \& editing, V.J. All authors have read and agreed to the published version of the manuscript.

Funding: This research received no external funding.

Institutional Review Board Statement: Not Applicable.

Informed Consent Statement: Not Applicable.

Conflicts of Interest: The authors declare no conflict of interest.

\section{References}

1. Farrand, K.F.; Fridman, M.; Stillman, I.Ö.; Schaumberg, D.A. Prevalence of diagnosed dry eye disease in the United States among adults aged 18 years and older. Am. J. Ophthalmol. 2017, 182, 90-98. [CrossRef] [PubMed]

2. Craig, J.P.; Nichols, K.K.; Akpek, E.K.; Caffery, B.; Dua, H.S.; Joo, C.K.; Liu, Z.; Nelson, J.D.; Nichols, J.J.; Tsubota, K.; et al. TFOS DEWS II Definition and classification report. Ocul. Surf. 2017, 15, 276-283. [CrossRef]

3. Nelson, J.D.; Craig, J.P.; Akpek, E.K.; Azar, D.T.; Belmonte, C.; Bron, A.J.; Clayton, J.A.; Dogru, M.; Dua, H.S.; Foulks, G.N.; et al. TFOS DEWS II introduction. Ocul. Surf. 2017, 15, 269-275. [CrossRef]

4. Akpek, E.K.; Amescua, G.; Farid, M.; Garcia-Ferrer, F.J.; Lin, A.; Rhee, M.K.; Varu, D.M.; Musch, D.C.; Dunn, S.P.; Mah, F.S. Dry eye syndrome preferred practice pattern. Ophthalmology 2019, 126, 286-334. [CrossRef] [PubMed]

5. Willcox, M.D.; Argüeso, P.; Georgiev, G.A.; Holopainen, J.M.; Laurie, G.W.; Millar, T.J.; Papas, E.B.; Rolland, J.P.; Schmidt, T.A.; Stahl, U.; et al. TFOS DEWS II tear film report. Ocul. Surf. 2017, 15, 366-403. [CrossRef] [PubMed]

6. Jones, L.; Downie, L.E.; Korb, D.; Benitez-del-Castillo, J.M.; Dana, R.; Deng, S.X.; Dong, P.N.; Geerling, G.; Hida, R.Y.; Liu, Y.; et al. TFOS DEWS II management and therapy report. Ocul. Surf. 2017, 15, 575-628. [CrossRef] 
7. Medical Device. Dry Eye Syndrome Market Size, Share \& Growth. Available online: https:/ /www.fortunebusinessinsights.com/ dry-eye-syndrome-market-102413 (accessed on 10 June 2020).

8. Food and Drug Administration. Ophthalmic drug products for over-the-counter human use; final monograph 21 CFR parts 349 and 369. Fed. Regist. 1988, 53, 7076-7093.

9. Paugh, J.R.; Nguyen, A.L.; Ketelson, H.A.; Christensen, M.T.; Meadows, D.L. Precorneal residence time of artificial tears measured in dry eye subjects. Optom. Vis. Sci. 2008, 85, 725-731. [CrossRef]

10. Benelli, U. Systane lubricant eye drops in the management of ocular dryness. Clin. Ophthalmol. 2011, 5, 783-790. [CrossRef]

11. Peluso, G.; Barbarisi, A.; Savica, V.; Reda, E.; Nicolai, R.; Benatti, P.; Calvani, M. Carnitine: An osmolyte that plays a metabolic role. J. Cell. Biochem. 2000, 80,1-10. [CrossRef]

12. Garrett, Q.; Xu, S.; Simmons, P.A.; Vehige, J.; Flanagan, J.L.; Willcox, M.D. Expression and localization of carnitine/organic cation transporter OCTN1 and OCTN2 in ocular epithelium. Investig. Ophthalmol. Vis. Sci. 2008, 49, 4844-4849. [CrossRef] [PubMed]

13. Xu, S.; Flanagan, J.L.; Simmons, P.A.; Vehige, J.; Willcox, M.D.; Garrett, Q. Transport of L-carnitine in human corneal and conjunctival epithelial cells. Mol. Vis. 2010, 16, 1823-1831. [PubMed]

14. Baudouin, C.; Aragona, P.; Messmer, E.M.; Tomlinson, A.; Calonge, M.; Boboridis, K.G.; Akova, Y.A.; Geerling, G.; Labetoulle, M.; Rolando, M. Role of hyperosmolarity in the pathogenesis and management of dry eye disease: Proceedings of the OCEAN group meeting. Ocul. Surf. 2013, 11, 246-258. [CrossRef]

15. Jain, N.K.; Roy, I. Effect of trehalose on protein structure. Protein Sci. 2009, 18, 24-36. [CrossRef]

16. Hill-Bator, A.; Misiuk-Hojło, M.; Marycz, K.; Grzesiak, J. Trehalose-based eye drops preserve viability and functionality of cultured human corneal epithelial cells during desiccation. Biomed Res. Int. 2014, 2014, 292139. [CrossRef]

17. Matsuo, T. Trehalose protects corneal epithelial cells from death by drying. Br. J. Ophthalmol. 2001, 85, 610-612. [CrossRef]

18. Balazs, E.A. Sodium hyaluronate and viscosurgery. In Healon: A Guide to Its Use in Ophthalmic Surgery; Millerm, D., Stegmann, R., Eds.; John Wiley \& Sons: Hoboken, NJ, USA, 1983; pp. 5-28.

19. Rah, M.J. A review of hyaluronan and its ophthalmic applications. Optometry 2011, 82, 38-43. [CrossRef] [PubMed]

20. Ubels, J.; Clousing, D.; Van Haitsma, T.; Hong, B.S.; Stauffer, P.; Asgharian, B.; Meadows, D. Pre-clinical investigation of the efficacy of an artificial tear solution containing hydroxypropyl-guar as a gelling agent. Curr. Eye Res. 2004, 28, 437-444. [CrossRef]

21. Rangarajan, R.; Kraybill, B.; Ogundele, A.; Ketelson, H.A. Effects of a hyaluronic acid/hydroxypropyl guar artificial tear solution on protection, recovery, and lubricity in models of corneal epithelium. J. Ocul. Pharmacol. Ther. 2015, 31, 491-497. [CrossRef]

22. Khanal, S.; Tomlinson, A.; Pearce, E.I.; Simmons, P.A. Effect of an oil-in-water emulsion on the tear physiology of patients with mild to moderate dry eye. Cornea 2007, 26, 175-181. [CrossRef]

23. Maïssa, C.; Guillon, M.; Simmons, P.; Vehige, J. Effect of castor oil emulsion eyedrops on tear film composition and stability. Contact Lens Ant. Eye 2010, 33, 76-82. [CrossRef]

24. Hasegawa, T.; Amako, H.; Yamamoto, T.; Tazawa, M.; Sakamoto, Y. Corneal-protective effects of an artificial tear containing sodium hyaluronate and castor oil on a porcine short-term dry eye model. J. Vet. Med. Sci. 2014, 76, 1219-1224. [CrossRef] [PubMed]

25. Epstein, S.P.; Ahdoot, M.; Marcus, E.; Asbell, P.A. Comparative toxicity of preservatives on immortalized corneal and conjunctival epithelial cells. J. Ocul. Pharmacol. Ther. 2009, 25, 113-119. [CrossRef]

26. Zhang, H.; Wu, H.; Yang, J.; Ye, J. Sodium perbarate and benzalkonium chloride induce DNA damage in Chang conjunctival epithelial cells. Cutan. Ocul. Toxicol. 2017, 36, 336-342. [CrossRef]

27. Corrales, R.M.; Luo, L.; Chang, E.Y.; Pflugfelder, S.C. Effects of osmoprotectants on hyperosmolar stress in cultured human corneal epithelial cells. Cornea 2008, 27, 574-579. [CrossRef] [PubMed]

28. Deng, R.; Su, Z.; Hua, X.; Zhang, Z.; Li, D.Q.; Pflugfelder, S.C. Osmoprotectants suppress the production and activity of matrix metalloproteinases induced by hyperosmolarity in primary human corneal epithelial cells. Mol. Vis. 2014, 20, 1243-1252.

29. Hua, X.; Deng, R.; Li, J.; Chi, W.; Su, Z.; Lin, J.; Pflugfelder, S.C.; Li, D.Q. Protective effects of L-carnitine against oxidative injury by hyperosmolarity in human corneal epithelial cells. Investig. Ophthalmol. Vis. Sci. 2015, 56, 5503-5511. [CrossRef]

30. Hua, X.; Su, Z.; Deng, R.; Lin, J.; Li, D.Q.; Pflugfelder, S.C. Effects of L-carnitine, erythritol and betaine on pro-inflammatory markers in primary human corneal epithelial cells exposed to hyperosmotic stress. Curr. Eye Res. 2015, 40, 657-667. [CrossRef] [PubMed]

31. Giuseppe, G.; Michela, F.; Piera, V. A novel osmoprotectant tear substitute for the treatment of dry eye disease. Int. J. Ophthalmol. Clin. Res. 2016, 3, 58 .

32. Labetoulle, M.; Chiambaretta, F.; Shirlaw, A.; Leaback, R.; Baudouin, C. Osmoprotectants, carboxymethylcellulose and hyaluronic acid multi-ingredient eye drop: A randomised controlled trial in moderate to severe dry eye. Eye 2017, 31, 1409-1416. [CrossRef]

33. Orobia, A.J.M.; Saa, J.; Lorenzo, A.O.; Herreras, J.M. Combination of hyaluronic acid, carmellose, and osmoprotectants for the treatment of dry eye disease. Clin. Ophthalmol. 2018, 12, 453-461. [CrossRef]

34. Chen, W.; Zhang, X.; Liu, M.; Zhang, J.; Ye, Y.; Lin, Y.; Luyckx, J.; Qu, J. Trehalose protects against ocular surface disorders in experimental murine dry eye through suppression of apoptosis. Exp. Eye Res. 2009, 89, 311-318. [CrossRef] [PubMed]

35. Chiambaretta, F.; Doan, S.; Labetoulle, M.; Rocher, N.; El Fekih, L.; Messaoud, R.; Khairallah, M.; Baudouin, C.; HA-trehalose Study Group. A randomized, controlled study of the efficacy and safety of a new eyedrop formulation for moderate to severe dry eye syndrome. Eur. J. Ophthalmol. 2017, 27, 1-9. [CrossRef] [PubMed] 
36. Li, J.; Roubeix, C.; Wang, Y.; Shi, S.; Liu, G.; Baudouin, C.; Chen, W. Therapeutic efficacy of trehalose eye drops for treatment of murine dry eye induced by an intelligently controlled environmental system. Mol. Vis. 2012, 18, 317-329.

37. Schmidl, D.; Schmetterer, L.; Witkowska, K.J.; Unterhuber, A.; dos Santos, V.A.; Kaya, S.; Nepp, J.; Baar, C.; Rosner, P.; Werkmeister, R.M.; et al. Tear film thickness after treatment with artificial tears in patients with moderate dry eye disease. Cornea 2015, 34, 421-426. [CrossRef] [PubMed]

38. Gomes, J.A.; Amankwah, R.; Powell-Richards, A.; Dua, H.S. Sodium hyaluronate (hyaluronic acid) promotes migration of human corneal epithelial cells in vitro. Br. J. Ophthalmol. 2004, 88, 821-825. [CrossRef]

39. Inoue, M.; Katakami, C. The effect of hyaluronic acid on corneal epithelial cell proliferation. Investig. Ophthalmol. Vis. Sci. 1993, 34, 2313-2315.

40. Sugiyama, T.; Miyauchi, S.; Machida, A.; Miyazaki, K.; Tokuyasu, K.; Nakazawa, K. The effect of sodium hyaluronate on the migration of rabbit corneal epithelium. II. The effect of topical administration. J. Ocul. Pharmacol. 1991, 7, 53-64. [CrossRef] [PubMed]

41. Kojima, T.; Nagata, T.; Kudo, H.; Müller-Lierheim, W.G.K.; van Setten, G.B.; Dogru, M.; Tsubota, K. The Effects of High Molecular Weight Hyaluronic Acid Eye Drop Application in Environmental Dry Eye Stress Model Mice. Int. J. Mol. Sci. 2020, 21, 3516, PMCID:PMC7278919. [CrossRef] [PubMed]

42. Stiebel-Kalish, H.; Gaton, D.D.; Weinberger, D.; Loya, N.; Schwartz-Ventik, M.; Solomon, A. A comparison of the effect of hyaluronic acid versus gentamicin on corneal epithelial healing. Eye 1998, 12, 829-833. [CrossRef]

43. Walsh, K.; Jones, L. The use of preservatives in dry eye drops. Clin. Ophthalmol. 2019, 13, 1409-1425. [CrossRef]

44. Noecker, R. Effects of common ophthalmic preservatives on ocular health. Adv. Ther. 2001, 18, 205-215. [CrossRef] [PubMed]

45. Oyejide, A.; Matsumoto, S.; Chang, J.; Tarlo, K.; Holland, M.; Whitcup, S.M.; Short, B. Comparative ocular histopathological effects of eye drops containing Purite (R) (Oxychloro Complex) or benzalkonium chloride preservatives in rabbits. Investig. Ophthalmol. Vis. Sci. 2003, 44, 1365.

46. Noecker, R.J.; Herrygers, L.A.; Anwaruddin, R. Corneal and conjunctival changes caused by commonly used glaucoma medications. Cornea 2004, 23, 490-496. [CrossRef] [PubMed]

47. Schrage, N.; Frentz, M.; Spoeler, F. The Ex Vivo Eye Irritation Test (EVEIT) in evaluation of artificial tears: Purite-preserved versus unpreserved eye drops. Graefes Arch. Clin. Exp. Ophthalmol. 2012, 250, 1333-1340. [CrossRef] [PubMed]

48. Rolando, M.; Crider, J.Y.; Kahook, M.Y. Ophthalmic preservatives: Focus on polyquaternium-1. Expert. Opin. Drug Deliv. 2011, 8, 1425-1438. [CrossRef] [PubMed]

49. Brignole-Baudouin, F.; Riancho, L.; Liang, H.; Baudouin, C. Comparative in vitro toxicology study of travoprost polyquadpreserved, travoprost BAK-preserved, and latanoprost BAK-preserved ophthalmic solutions on human conjunctival epithelial cells. Curr. Eye Res. 2011, 36, 979-988. [CrossRef] [PubMed]

50. Brignole-Baudouin, F.; Riancho, L.; Liang, H.; Nakib, Z.; Baudouin, C. In vitro comparative toxicology of polyquad-preserved and benzalkonium chloride-preserved travoprost/timolol fixed combination and latanoprost/timolol fixed combination. J. Ocul. Pharmacol. Ther. 2011, 27, 273-280. [CrossRef]

51. Ammar, D.A.; Noecker, R.J.; Kahook, M.Y. Effects of benzalkonium chloride- and polyquad-preserved combination glaucoma medications on cultured human ocular surface cells. Adv. Ther. 2011, 28, 501-510. [CrossRef]

52. Paimela, T.; Ryhänen, T.; Kauppinen, A.; Marttila, L.; Salminen, A.; Kaarniranta, K. The preservative polyquaternium-1 increases cytoxicity and NF-kappaB linked inflammation in human corneal epithelial cells. Mol. Vis. 2012, 18, 1189-1196.

53. Liang, H.; Brignole-Baudouin, F.; Pauly, A.; Riancho, L.; Baudouin, C. Polyquad-preserved travoprost/timolol, benzalkonium chloride (BAK)-preserved travoprost/timolol, and latanoprost/timolol in fixed combinations: A rabbit ocular surface study. Adv. Ther. 2011, 28, 311-325. [CrossRef]

54. Labbé, A.; Pauly, A.; Liang, H.; Brignole-Baudouin, F.; Martin, C.; Warnet, J.M.; Baudouin, C. Comparison of toxicological profiles of benzalkonium chloride and polyquaternium-1: An experimental study. J. Ocul. Pharmacol. Ther. 2006, 22, 267-278. [CrossRef]

55. Lee, H.J.; Jun, R.M.; Cho, M.S.; Choi, K.R. Comparison of the ocular surface changes following the use of two different prostaglandin F2 $\alpha$ analogues containing benzalkonium chloride or polyquad in rabbit eyes. Cutan. Ocul. Toxicol. 2015, 34, 195-202. [CrossRef]

56. El Hajj Moussa, W.G.; Farhat, R.G.; Nehme, J.C.; Sahyoun, M.A.; Schakal, A.R.; Jalkh, A.E.; Abi Karam, M.P.; Azar, G.G. Comparison of efficacy and ocular surface disease index score between bimatoprost, latanoprost, travoprost, and tafluprost in glaucoma patients. J. Ophthalmol. 2018, 2018, 1319628. [CrossRef]

57. De Saint Jean, M.; Brignole, F.; Bringuier, A.F.; Bauchet, A.; Feldmann, G.; Baudouin, C. Effects of benzalkonium chloride on growth and survival of Chang conjunctival cells. Investig. Ophthalmol. Vis. Sci. 1999, 40, 619-630.

58. De Saint Jean, M.; Debbasch, C.; Brignole, F.; Rat, P.; Warnet, J.M.; Baudouin, C. Toxicity of preserved and unpreserved antiglaucoma topical drugs in an in vitro model of conjunctival cells. Curr. Eye. Res. 2000, 20, 85-94. [CrossRef]

59. Debbasch, C.; Brignole, F.; Pisella, P.J.; Warnet, J.M.; Rat, P.; Baudouin, C. Quaternary ammoniums and other preservatives' contribution in oxidative stress and apoptosis on Chang conjunctival cells. Investig. Ophthalmol. Vis. Sci. 2001, 42, 642-652.

60. Debbasch, C.; Pisella, P.J.; De Saint Jean, M.; Rat, P.; Warnet, J.M.; Baudouin, C. Mitochondrial activity and glutathione injury in apoptosis induced by unpreserved and preserved beta-blockers on Chang conjunctival cells. Investig. Ophthalmol. Vis. Sci. 2001, 42, 2525-2533. 
61. Pauly, A.; Meloni, M.; Brignole-Baudouin, F.; Warnet, J.M.; Baudouin, C. Multiple endpoint analysis of the 3D-reconstituted corneal epithelium after treatment with benzalkonium chloride: Early detection of toxic damage. Investig. Ophthalmol. Vis. Sci. 2009, 50, 1644-1652. [CrossRef] [PubMed]

62. Wilson, W.S.; Duncan, A.J.; Jay, J.L. Effect of benzalkonium chloride on the stability of the precorneal tear film in rabbit and man. Br. J. Ophthalmol. 1975, 59, 667-669. [CrossRef]

63. Chung, S.H.; Lee, S.K.; Cristol, S.M.; Lee, E.S.; Lee, D.W.; Seo, K.Y.; Kim, E.K. Impact of short-term exposure of commercial eyedrops preserved with benzalkonium chloride on precorneal mucin. Mol. Vis. 2006, 12, 415-421.

64. Ichijima, H.; Petroll, W.M.; Jester, J.V.; Cavanagh, H.D. Confocal microscopic studies of living rabbit cornea treated with benzalkonium chloride. Cornea 1992, 11, 221-225. [CrossRef]

65. Chen, W.; Li, Z.; Hu, J.; Zhang, Z.; Chen, L.; Chen, Y.; Liu, Z. Corneal alternations induced by topical application of benzalkonium chloride in rabbit. PLoS ONE 2011, 6, 26103. [CrossRef]

66. Kahook, M.Y.; Noecker, R. Quantitative analysis of conjunctival goblet cells after chronic application of topical drops. Adv. Ther. 2008, 25, 743-751. [CrossRef]

67. Sarkar, J.; Chaudhary, S.; Namavari, A.; Ozturk, O.; Chang, J.H.; Yco, L.; Sonawane, S.; Khanolkar, V.; Hallak, J.; Jain, S. Corneal neurotoxicity due to topical benzalkonium chloride. Investig. Ophthalmol. Vis. Sci. 2012, 53, 1792-17802. [CrossRef] [PubMed]

68. Chen, W.; Zhang, Z.; Hu, J.; Xie, H.; Pan, J.; Dong, N.; Liu, Z. Changes in rabbit corneal innervation induced by the topical application of benzalkonium chloride. Cornea 2013, 32, 1599-1606. [CrossRef] [PubMed]

69. Jaenen, N.; Baudouin, C.; Pouliquen, P.; Manni, G.; Figueiredo, A.; Zeyen, T. Ocular symptoms and signs with preserved and preservative-free glaucoma medications. Eur. J. Ophthalmol. 2007, 17, 341-349. [CrossRef] [PubMed]

70. Pucker, A.D.; Ng, S.M.; Nichols, J.J. Over the counter (OTC) artificial tear drops for dry eye syndrome. Cochrane Database Syst. Rev. 2016, 2, CD009729. [CrossRef] [PubMed]

71. Moshirfar, M.; Pierson, K.; Hanamaikai, K.; Santiago-Caban, L.; Muthappan, V.; Passi, S.F. Artificial tears potpourri: A literature review. Clin. Ophthalmol. 2014, 8, 1419-1433. [PubMed]

72. Lievens, C.; Berdy, G.; Douglass, D.; Montaquila, S.; Lin, H.; Simmons, P.; Carlisle-Wilcox, C.; Vehige, J.; Haque, S. Evaluation of an enhanced viscosity artificial tear for moderate to severe dry eye disease: A multicenter, double-masked, randomized 30-day study. Cont. Lens Ant. Eye 2019, 42, 443-449. [CrossRef] [PubMed]

73. Essa, L.; Laughton, D.; Wolffsohn, J.S. Can the optimum artificial tear treatment for dry eye disease be predicted from presenting signs and symptoms? Cont. Lens Ant. Eye 2018, 41, 60-68. [CrossRef] [PubMed]

74. Vandermeer, G.; Chamy, Y.; Pisella, P.J. Comparison of objective optical quality measured by double-pass aberrometry in patients with moderate dry eye: Normal saline vs. artificial tears: A pilot study. J. Fr. Ophtalmol. 2018, 41, e51-e57. [CrossRef] [PubMed]

75. Markoulli, M.; Sobbizadeh, A.; Tan, J.; Briggs, N.; Coroneo, M. The effect of optive and optive advanced artificial tears on the healthy tear film. Curr. Eye Res. 2018, 43, 588-594. [CrossRef] [PubMed] 